\title{
ポリプロピレン繊維の染色に関する研究 $\alpha$-ナフトールによる染着性の增大について
}

\author{
岐阜大学工学部 高瀬 福巳・矢留智津子 \\ STUDIES ON THE DYEING OF POLYPROPYLENE FIBRE. INCREASE \\ IN THE AMOUNT OF ADSORPTION OF DYES WITH $a$-NAPHTHOL
}

\author{
By Yoshimi Takashe and Chizuko Yatome
}

(Faculty of Engineering, Gifu University, Naka Machi, Gifu Prefecture, Japan)

The dyeing by the use of carrier often applied to increase the amount of adsorption of dyes in the dyeing of polypropylene fibre with cationic dyes (Sevron dyes) was studied. From the point of view that the effects of carrier is due to the degree of swelling of fibre in liquids, first of all, the selection of carrier was based upon the theory of solubility parameter which express the swelling and solution. of fibre-forming polymers in liquids. When the polymer is not too polar, the closer the solubility. parameter of the liquid is to that of polymer, the greater is the degree of swelling. Therefore some organic compounds which have a solubility parameter not too far from that of polypropylene fibre wereused as carriers. The following conclusions were obtained.

A neutral or slightly alkaline dyebath is suitable for the dyeing of polypropylene fibre with Sevron dyes. The most commonly used carrier for polyester fibre, such as 0 -phenyl phenol and $p$-phenyl phenol, and $\alpha$-naphthol are effective. The optimum concentration of these carriers for maximum adsorption of dyes is $1.5 \mathrm{~mol} / \mathrm{kg}$. In applying the method of carrier, it is recommended that the carrier solution. pretreated fibre should be dyed in the bath containing the same carrier. In selecting carriers upon thetheory of solubility parameter, though solubility parameter may be a basis of the selection, it is desirable to correct the solubility parameter of fibre, for it is only an approximate number and besides, polypropylene fibre contains too much crystalline region.

(Received December 4, 1961)

\section{1. 緒喜}

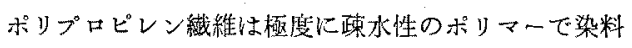
吸福に有効な活性基を保有せず，染色の解決万法として 織維の改質，特殊な染料の合成，染色法の改善などが考 えられている。これをで合成瀻維の嚾染性に刘しては， 䋐維内の染料扗散速度を增大寸る染色法がとられてい、 る。すなわら，染料分子の微小化，キャリヤー染色，高 温染色などりあるが，本实験てはアクリロニトリル合成 織維用のカチオン染料を用い，主としてキャリヤー染色 について検討した。

\section{2. キャリヤーによる膨潤理論}

現在多くの有機化合物がキャリヤーとして有効であ る。しかるにてれらの機構は簡単なるのでなく、キャリ ヤーの静造, 性質などとの間の完全に統一した関係は見
出されなく，一般に染浴に㧍ける染料の可溶化，織維の 膨潤, 維の柔颙可㷱化, 新しい染着活传点の生成など. 1,2,3があげられている。

本報はまずキャりサー作用は緎維を膨潤させるという 見地から，膨潤溶解に関する溶解度パラメーター（以下 $\delta$ と略す) の理諭を適用しキャリ+ーの選定を試み

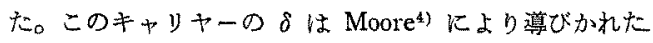
次式で計算される。

$$
\delta=\left(\frac{L_{e}-R T}{V}\right)^{1 / 2}
$$

$$
\begin{aligned}
& L_{e}: \text { 蒸発のモル潜熱 } \\
& V: T \text { に括け分子容 } \\
& R: \text { 気体定数 } \\
& \text { ただし }
\end{aligned}
$$

$$
L_{\varepsilon}=23.7 T_{b}+0.02 T_{b}^{2}-2950
$$

$T_{b}$ : 沸点の秝対温度 


$$
V=\frac{\text { 分子量 }}{\text { 密 }}
$$

またキャリャーとして2 液体の混合物を使用する場合に 快，次の上万計算される。

$$
\delta_{M}=\delta_{1} v_{1}+\delta_{2} v_{2}
$$

$v_{1}, v_{2}$ 法混合物中の 2 液体の容量分率

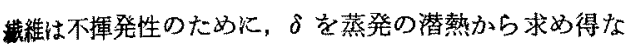
い。徒つて Smal1 ${ }^{5\rangle}$ の提唱したポりーー概略檤の方法,

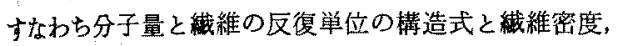
反复単位中のそれそれの基怙よび構造により確定された “分子引力定数”により計算される。いまポリプロピレン 維の反復単位を $-\mathrm{CH}_{2}-\mathrm{CH} \mathrm{CH}$ - とすると分子量 $M_{0}=42.046$, 密度 $d=0.90$, 分子引力定数 $\left(-\mathrm{CH}_{3}=214\right.$, $\left.>\mathrm{CH}=28,>\mathrm{CH}_{2}=133\right)=375$ となるから

$$
\delta=\frac{\text { 分子引力定数 } \times d}{M^{0}}=8.0
$$

と計算される。

熱力学的に導かれたこの式と㧊いて，極性の少ない䋐 維の $\delta$ に対して溶媒が $\delta \pm 1.5$ Kあれば溶解が技こり,

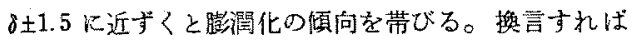

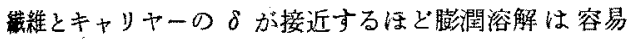

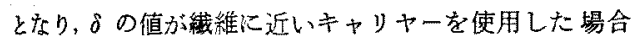
染色上の效果が期待できる。

\section{3. 試料および実験方法}

原料社アピサン社整永りプロピレン，東亜紡にて紡系， 2.5 デニール，100 $\mathrm{C} ， 3$ 倍の延伸した紻維である。こ れを $5 \mathrm{~g} / l$ のアニオン活性戍溶夜で $60 \sim 70^{\circ} \mathrm{C}$ て処理 し，水洗，風乾して温度一定のデシケータ中に䝪藏，試 料㐳供した。染料住セブロン染料数種を用い，キャリヤ

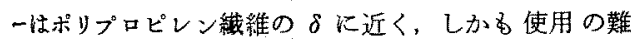
易，毒性などの条件を考當して数重を選んだ。親水性キ

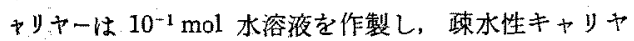
ーはフルコール $10 \mathrm{ml}$ に溶かし $10^{-1} \mathrm{~mol}$ 溶花を作製し て所要量家浴中に注加した。oーフェニルフェノール, $p$ $フ_{エ}$ ニルェノールは水酸化ナトリウムに溶解し, 醀酸 で分散させた。

実駼方法は染料濃度 $3 \%$ (o.w.f.) , キャリヤ一, 浴 此 $1: 100$, 温度 $95^{\circ} \mathrm{C}$ の条件とした。染色に祭し，50 m $l$ 三角フラスコのキャリヤー添加溶液に染料溶液を注加 し，95C の水浴中江入れ染色し残液法 な大性抽出法で 比色定量し染料の吸着量とした。残液比色では綞維へ 物理的伿付着している染料は多量であるから，表面の染 料完全に脱落させるたらに数回の水洗を要する。染料 の媑類に上り水洗回数を異にするが，染色残液と水洗液 とをまぜ全量を $100 \mathrm{~m} l$ とし比色定量試料とした。こ
の残夜法は一般沉染着量の少ない紻維では誤差を生じや すく，またキャリヤーを使用した場合恃残液が乳濁して 籣単绝比色できない乳濁液はアルニール，アセトン， ピリジンなとの有機溶媒を加えると溶解するが，多量の 溶媒を必要とする。上つて乳濁夜化は手数はやや要する が正確かつ経済的な抽出法を採用した。カチオン染料は アセトンどリジンで抽出できるがフセトンは濃度变化 を考虑しなければならないのでピリジンの $50 \%$ 溶液で 抽出した。なお三角フラスコで染色する时液の蒸発を 避けるため空気冷却器を使用した。

\section{4. 結果および考察}

ポりプロピレン䄉維のセブロン染料仙上る染色におい て，アクリロニトリル紻維の標準酸性浴6,7)では，染着 が活とんど認められない。第1図の上5飞染浴の $\mathrm{pH}$ を 高めると染着量がやや增大するが，いずれる淡色握度に

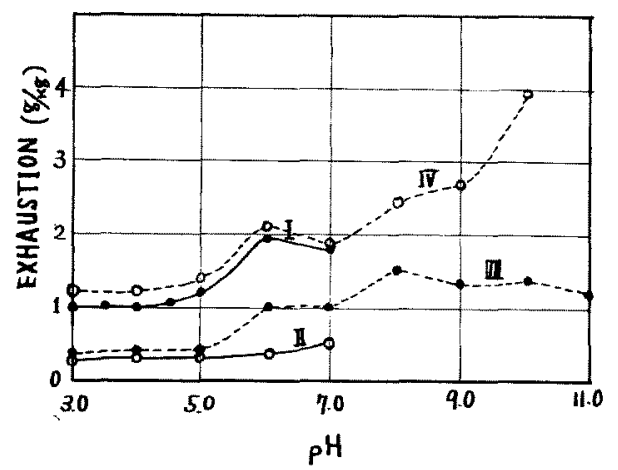

Fig. 1. Relations between exhaustion and $\mathrm{pH}$ of bath. (Dyes $3 \%$, at $95^{\circ} \mathrm{C}$, for $120 \mathrm{~min}$.)

I. ... Sevron Orange G, II. ... Sevron Blue $5 \mathrm{G}$,

\begin{tabular}{|c|c|c|c|}
\hline & & 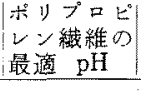 & 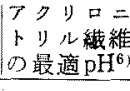 \\
\hline Sevron & Orange $G$ & $6 \sim 7$ & - \\
\hline " & Blue $\quad 5 \mathrm{G}$ & $"$ " & - \\
\hline$" \prime$ & Green $\mathrm{B}$ & $" \prime$ & - \\
\hline$" \prime$ & Yellow R & $"$ & $4.0 \sim 5.5$ \\
\hline$" \prime$ & Yellow L & $"$ & $4.0 \sim 5.5$ \\
\hline$" \prime$ & Brilliant Red B & $"$ & - \\
\hline$"$ & Red GL & $8 \sim 9$ & - \\
\hline$" 1$ & Blue & $"$ & $4 \sim 8$ \\
\hline " & Orange $\mathrm{L}$ & $"$ & $5 \sim 8$ \\
\hline$"$ & Blue $2 \mathrm{G}$ & " & $4 \sim 8$ \\
\hline$"$ & Yellow $3 \mathrm{RL}$ & $" 1$ & - \\
\hline$" \prime$ & Red L & $"$ & $5 \sim 8$ \\
\hline$" 1$ & Blue BGL & $" 1$ & 一 \\
\hline
\end{tabular}

III. ...Sevron Red GL, IV. ...Sevron Blue B. 第 1 表 各種染料と染浴の最適 $\mathrm{pH}$ 


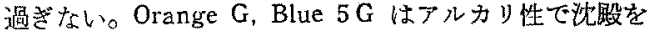
生成するため pH 7.0 まで测定した。はたカチオン染料 は一般に染浴の pH が高くなると色素塩基が遊離するた め7 $\mathrm{pH}$ は 8〜9にとどめなければならない。そこで第 1 表のよ5にポリプロピレン䋐維の染色で $\mathrm{pH}$ を高める と沈琪を生成しますいものは pH 6〜7, pH をかなり高 めて字沈殿を生成しないものは pH 8〜9のアルカリ性 の染浴で染色学るのが適当と思加る。この条件で染色 した場合，䋐維表面の染料濃度はかり高漕度となつてい るが，繊維内部の染料分子の結合は少なく，水洗すると

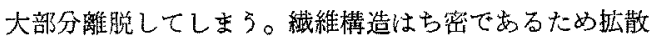
速度がおそく，カチオン染料に対主る特定の染着座席は

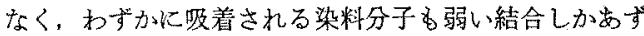
办占办。

次に数種のキャリヤーを選び染色した結果を第 2 流に 示与。キャリヤ一使用に离たり分散凨として非イオン活 性剂，多作アルコール系のサフォノール(三洋)，ポリオ キシェチレンアルキルフェノール系のノニポールB（三

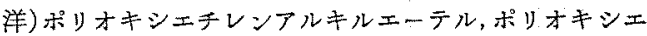
チレンアルキルアミン，ポリオキシエチレンブルルア ミド配合のデスパノールM(ニッサン)なととついて娭討
したが，いずれす緩染作用が優先して效果か゚少なから た。キャリャー効果は分散斉の種類，分散方法により大 いK異なるので一概にいえないが，本実験においては第 2 表のよ5に, oーフェニルフェノール, $p$ ーフニルフェ ノールなどポリェステル戴維の染色儿使用されているす のや， $\alpha$ ナフトールが染着量の增大を示した。の-醀酸 ブチル，トルエン，ベンゼンはそのまま添加した場合に は溶液中て均一に分散しない。”た $\alpha$ ーナフトール， $\beta$ ナフトールなどはさら染めとなるためアルコールに溶解 すると均一に分散する。

これら化合物のるに注目すると，ポリプロピレン裁 維の $\delta$ に最近い $n$ 一䣫酸ブチルはキャリヤ一無添加ま たはやや $\delta$ 大きいピりジン、フェノールなどと活同 じ染着量であり，一方かなり大きい $\delta$ を示す $\alpha$-ナフト ールのアルコール混合溶液では染着量が増大している。 また 䣫酸 ブチル，トルエン，ベンゼンなどのアルコ 一ル混合溶激に势いては染着量は增大していない。この

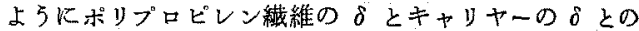
関係は理諭と必ずしも一致しない結果となつた。次にポ リプロピレン㵶維の有機溶剂仁対する溶解性の順位 ${ }^{8)}$ と $\delta$ との関係を求める。四塩化エチレン $(\delta=10.7)>ト リ$

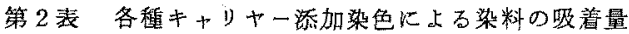

\begin{tabular}{|c|c|c|c|c|c|c|c|c|c|}
\hline \multirow[b]{2}{*}{$\neq+y+-$} & \multirow[b]{2}{*}{ 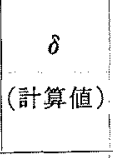 } & \multicolumn{4}{|c|}{ Sevron Blue B } & \multicolumn{4}{|c|}{ Sevron Orange $\mathrm{G}$} \\
\hline & & $\begin{array}{c}\text { 染浴 } \\
\mathrm{pH}\end{array}$ & $\begin{array}{l}\text { 染盖畺 } \\
(\mathrm{g} / \mathrm{kg})\end{array}$ & 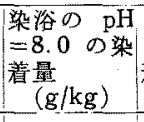 & $\begin{array}{l}\text { y- ピン } \\
\text { グ 後の染 } \\
\text { 着量 } \\
(\mathrm{g} / \mathrm{kg}))\end{array}$ & $\begin{array}{c}\text { 染浴口 } \\
\mathrm{pH}\end{array}$ & $\begin{array}{l}\text { 染盖置 } \\
(\mathrm{g} / \mathrm{kg})\end{array}$ & 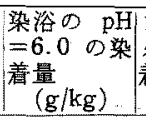 & $\begin{array}{l}y-ヒ^{\circ} \\
ク ゙ \text { 後の染 } \\
\text { 䫞量 } \\
(\mathrm{g} / \mathrm{kg}) \\
\end{array}$ \\
\hline ボリプロと゚レン㧴維 & 8.0 & $\cdots$ & - & $-i$ & - & 一 & - & $一$ & - \\
\hline$\neq+y+-$ 無添加 & 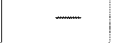 & 6.5 & 2.34 & 2. 49 & 1.17 & 6.5 & 1.32 & 2.01 & 1.59 \\
\hline$n$ 一酢 酸ブチム & 8.5 & 6.4 & $2.49^{*}$ & - & - & 6.4 & $2.49^{*}$ & - & - \\
\hline トルエ $エ ン$ & 8.9 & 6.4 & 2. $49 *$ & - & - & 6.4 & $1.65^{*}$ & - & - \\
\hline ベン ゼ ソ & 9.2 & 6.8 & $2.64^{*}$ & 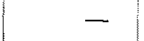 & - & 6.8 & 1. $32^{*}$ & 一 & - \\
\hline $7 \quad \bullet \quad ト \quad$ & 9.8 & 6.35 & 1.32 & 2. 49 & 1.32 & 6.35 & 0.33 & 2.34 & 2.01 \\
\hline$E^{*} \quad$ y $\quad \forall \quad ン$ & 10.4 & 7.1 & 2.49 & 2.49 & 1.32 & 7.1 & 8.67 & 6.33 & 5.82 \\
\hline$\alpha \omega \rightarrow>-M$ & 11.2 & 5.5 & $8.67^{*}$ & 一 & - & 5.5 & $9.42^{*}$ & $\therefore$ & - \\
\hline $7 x,-H$ & 11.6 & 6.8 & 1.32 & 1.32 & 0.33 & 6.8 & 0.66 & 1.50 & 1.32 \\
\hline$\beta-ナ>ト-ル$ & 11.8 & 5.5 & $5.01^{*}$ & - & - & 5.5 & $3.84^{*}$ & 一 & - \\
\hline 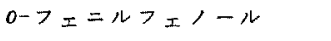 & - & 5.7 & 9.33 & 16.17 & 7.17 & 5.7 & 6.51 & 8. 16 & 4.83 \\
\hline$p-フ ェ ニ ル フ ェ ノ-ル$ & - & 10.9 & 5.16 & 11.40 & 4.08 & 10.9 & 2. 49 & 15.96 & 12.99 \\
\hline$n$ 一酢酸ブチル十エターール & 13.0 & 6.4 & 1.68 & 2.49 & 1.32 & 6.4 & 1.32 & 1.32 & 0.99 \\
\hline トルメンサ×タノール & 13.0 & 6.4 & 1.68 & 2.49 & 1.32 & 6.4 & 1.32 & 2.01 & 1.50 \\
\hline ベンゼンサエタノール & 13.0 & 6.8 & 1.32 & 2.49 & 1.65 & 6.8 & 0.66 & 1.50 & 1.26 \\
\hline 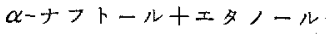 & 13.1 & 5.5 & 8. 49 & 10.32 & 6.90 & 5.5 & 9.33 & 9. 42 & 7.41 \\
\hline 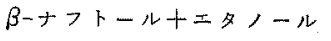 & 13.1 & 5.5 & 2.68 & 2.34 & 1.35 & 5.5 & 5. 16 & 5.67 & 5.01 \\
\hline
\end{tabular}

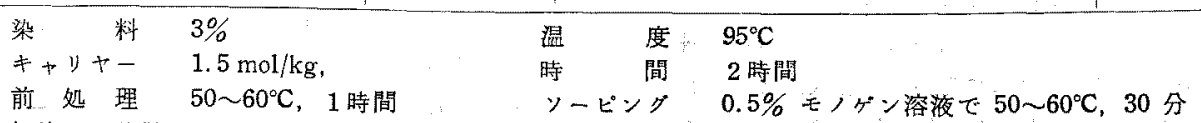

*场一に分散していない, むら染めとなる。 


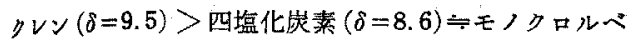

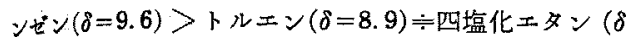
9.9)〉テトラリン $(\delta=9.8)>$ キシレン $(\delta=9.3)>n$ ヘンソタン $(\delta=7.4)>0$ ージクロルベンゼン $(\delta=10.9)$ であ ク $\delta$ の值が 10.0 K近い範囲で溶解が起こつている。

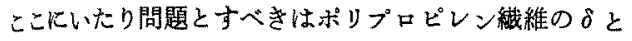
なつた。推定の基碟たる構造原子団当りの定数の適確な 法がだ確立されて括らず，諸氏により数值がかなり 異なつて括り，従つて上記有効なキャリヤーのよよりポ リプロピレン紻維の $\delta$ の理論值 8.0 よりもさらに大きく 10.0 前後にするのが妥当ではなからうか。一方 Small の分子引力定数は液状ポリマーの蒸気压およぴ気化熱よ り求めたるのであり，ボりブロピレン紼維の上らに結晶 部分の多い緎維熱力学的に不安定な状態にあるため誤 差定生じやすいとも考えられる。いずれ化してる有機溶 㜰の作用を膨澗能のみから求めるには $\delta$ 今゙今後補正され るであろらがキャリヤ一選定の一つの尺度として取扱 いやすい点は明らかになつた。

次に第2図の上5に，2，3のキャリ+ーについてその 溇度と染着量との関俰を求めた。アセトン・フェノールな とは高漫度にしても染着量が增大しないので効果は少な いと考它れる。ひ-ナフトールは $1.5 \mathrm{~mol} / \mathrm{kg}$ が限界濃 度でり，これ以上の濃度はむら染めとなり，染色䋐維 の色相変化する。の-フェニルフェノールも2.0 mol $/ \mathrm{kg}$ 以上になると色相の変化をきたすため， $1.5 \mathrm{~mol} / \mathrm{kg}$ まで が最適と思われる。

従来より 0 -フェニルフェノール, $p-エ_{x} ニ ル フ ェ ，$ 一ルはポリエステル織維に使用されているので，ここで は特に $\alpha$-ナフトールをとり岕壮染色条件について検討 した。寒験はキャリャーで前処理後染色した。その効

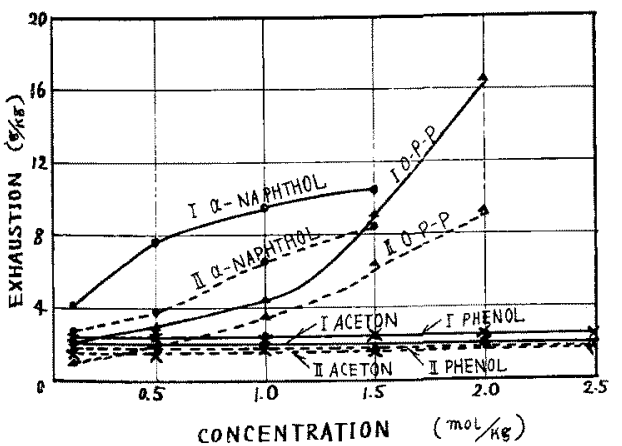

Fig. 2. Relations between exhaustion and the optimum concentration of carrier.

(Pretreatment at $50 \sim 60^{\circ} \mathrm{C}$, for $60 \mathrm{~min}$. Dyes $3 \%$, at $95^{\circ} \mathrm{C}$, for $120 \mathrm{~min}$.)

I. ... Sevron Blue B, II. ... Sevron Orange G

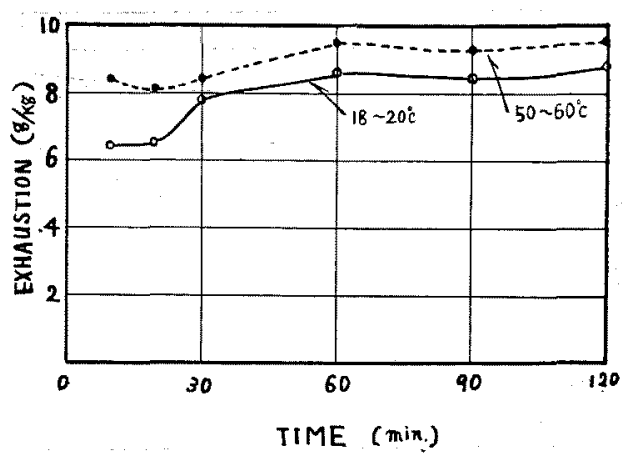

Fig. 3. Relations between exhaustion and temperature or time of pretreatment with carrier. (Sevron Blue B $3 \%, \alpha$-naphthol $1 \mathrm{~mol} / \mathrm{kg}$, at $95^{\circ} \mathrm{C}$, for $120 \mathrm{~min}$.)

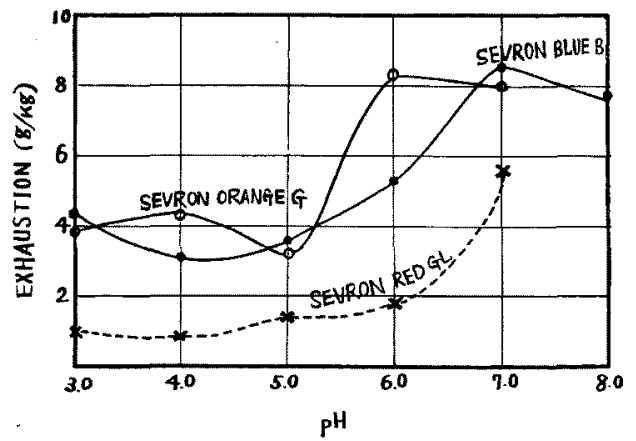

Fig. 4. Relations between exhaustion and $\mathrm{pH}$ of bath. $\left(\alpha\right.$-naphthol $1 \mathrm{~mol} / \mathrm{kg}$, pretreatment at $50 \sim 60^{\circ} \mathrm{C}$, for $30 \mathrm{~min}$.. Dyes $3 \%$, at $95^{\circ} \mathrm{C}$ for $120 \mathrm{~min}$.)

果については第3図のよ5に時間，温度ともにあまり関 保なく，すなわち前処理效果は認められなかつた。しか るに Blue B に批いては $1.5 \mathrm{~mol} / \mathrm{kg}$ の濃度においてて染 浴に同時添加し， $95^{\circ} \mathrm{C}$ で数時間加熱すると染料と区 応して沈皘を生成する。あらかじめキャリヤーで前処理 し染料を入れ $95^{\circ} \mathrm{C}$ の水浴中で界温すれば沈期は生成 せず，溶液は分教状態となるので $50 \sim 60^{\circ} \mathrm{C} て ゙ 30$ 分の 前处理は必要であろ5。次に染浴の $\mathrm{pH}$ と染着量の関 係は第 4図のようである。無添加の場合と同様， $\mathrm{pH}$ を 高めるほど染着量が增大する。この結果から 一ル添加の場合も無添加の最適 $\mathrm{pH} て ゙$ 染色すればよい と思われる。究た $\alpha$ オナフールの分散方法と染着量と の関係は第 5 図の結果となつた。水酸化ナトリウムに溶 解し酢酸で分散した染浴とアルュールに溶解して水中に 分散した場合では，前者の方が低濃度においても有効な ことが明白となつた。しかし染浴のナトリウムイオンが 染着量に影淛すると想像され，それをさけるためにはア ルコールに溶解し，水中に分散させせ使用することるす 


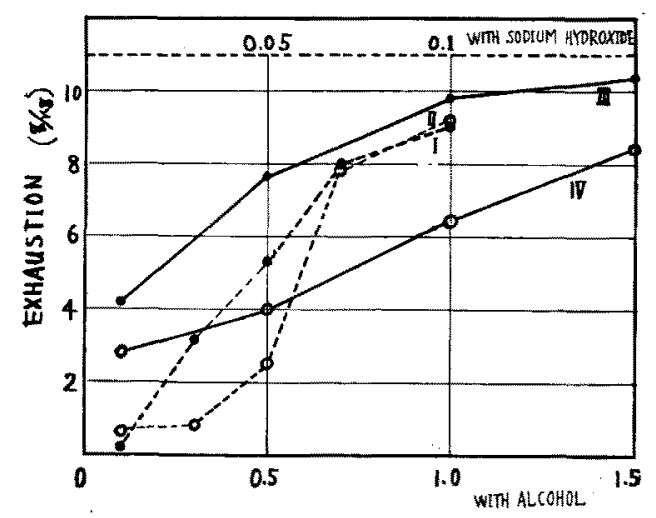

THE CONCENTRATION OF CARRIER (mol/s.

Fig.5. Relations between exhaustion and the disperesion method of $\alpha$-naphthol.

I....Predissolved $\alpha$-naphthol with sodium hydroxide dispersed by adding acetic acid.

(Sevron Blue B)

II... " (Sevron Orange G)

III. ..Predissolved $\alpha$-naphthol with alcohol added to bath.

(Sevron Blue B)

IV. $\cdots$

(Sevron Orange G)

(Pretreatment at $50 \sim 60^{\circ} \mathrm{C}$, for $60 \mathrm{~min}$. Dyes $3 \%$, at $95^{\circ} \mathrm{C}$, for $120 \mathrm{~min}$.)

第 3 表 $\alpha-$

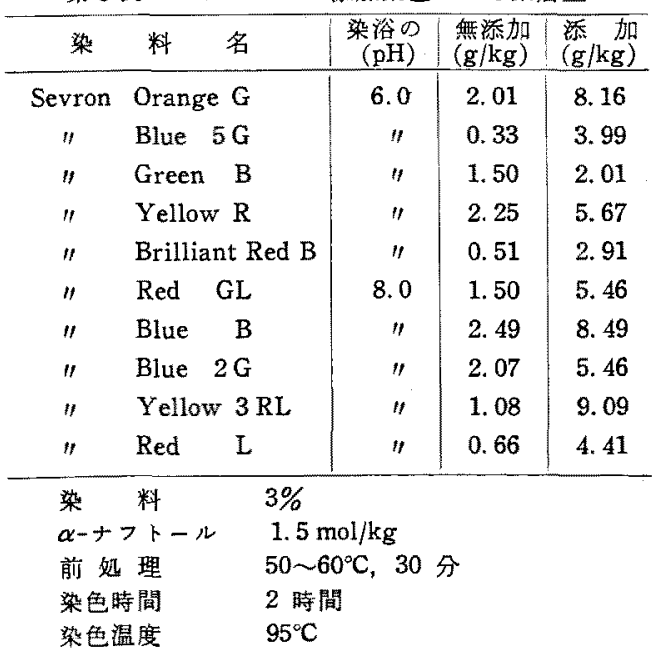

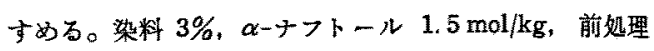
$50 \sim 60^{\circ} \mathrm{C}, 30$ 分, 温度 $95^{\circ} \mathrm{C}$, 時間 2 時間の染色条件 により数種の染料を用いて染色したところ第3表のよう にいすれの染料に和いてす， ば染着量はかなり增大した。

\section{5. 括}

ポリプロピレン霍維のカキオン染料による染色性向上 について検討した結果，次の上うな重要な知見を得た。

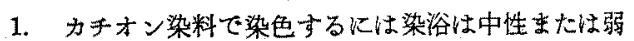
アルカリ性が適する。

2. キャリヤー選定方法として溶解度メ゙ラメータを浐 用するには，溶解度バラィータが概数ですり，瀻維の结 晶部分が比較的多いため，徒来上り提唱されているポり マーの計算方法をそのまま適用する上に補正を要する が, キャyャー選定の一つの基準后るるのと推定され る。

3. キャリヤーとしてポリエステル緎維に赛用されて いる

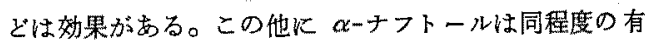
效性を有し，これが最適条件としてキャリヤ一濃度は $1.5 \mathrm{~mol} / \mathrm{kg}$ で前処理後染色するのがよいと結諭された。

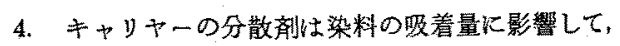

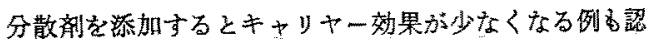
められる。一般に最適の分散剂の選定が困難な条件に㕲 いては，アルコールに溶解して水分散させるのがよいと 考える。

（付部）本研究は維維学会昭和 36 年秋期研究筧表会 て発表した。 文献

1) Vickerstaff ; The Physical Chemistry of Dyeing. 2 nd End (1954)

2) 失部; 械学誌, 12,770 (1956)

3) 矢部; 有合化, 14, 190 (1956)

4) Moore; J.Soc.Dyer Col., 73, 500 (1957)

5) Small ; J.Appl.Chem., 3, 71 (1953)

6) Clarke, Bidgood; Am. Dyes. Reptr., 44, 631 (1955)

7) Meldrun, Ward; J. Soc. Dyer Col., 74, 140 (1958)

8) 并上,川上; ポリブロピレン, p.56(ブラスチッ 材数譜座, 日刊工丵新聞社, 1961) 